Received: 2014.05.10 Accepted: 2014.07.25 Published: 2014.10.24

Authors' Contribution: Study Design A Data Collection B Statistical Analysis C Data Interpretation D Manuscript Preparation E

Literature Search F Funds Collection G

Corresponding Author: Conflict of interest:

\section{Management of Spindle Cell Carcinoma of the Maxillary Sinus: A Case Report and Literature Review}

Department of Otolaryngology, King Abdulaziz University, Jeddah, Saudi Arabia

Mohammed K. AlNoury, e-mail: M_k_nouri@hotmail.com

None declared

Patient:

Final Diagnosis:

Symptoms:

Medication:

Clinical Procedure:

Specialty:

Objective:

Background:

Case Report:

Conclusions:

MeSH Keywords:

Full-text PDF:
Male, 52

Spindle-cell carcinoma of the maxillary sinus

Functional endoscopic sinus surgery • total maxillectomy

Otolaryngology

\section{Rare disease}

Carcinosarcomas, also known as spindle cell carcinomas, are rare and highly aggressive tumors characterized by dual histologic differentiation of squamous cell and mesenchymal cell tumors. Occurrence of carcinosarcoma in maxillary sinus is very rare, with only 11 cases reported since 1957 . The small number of reported cases creates an obstacle to the increased understanding of the behavior, prognosis, and therapeutic management of this tumor.

A 52-year-old man presented with a 2-month history of right nasal obstruction. Computed tomography (CT) and magnetic resonance imaging (MRI) showed opacified right frontal, sphenoid, ethmoid, and maxillary sinuses with soft tissue density and expansion of the mass with erosion of the right lateral maxillary wall. Functional endoscopic sinus surgery (FESS) was done and histopathology revealed multiple fragments of nasal mucosa lined by stratified hyperplastic squamous epithelium with an increased degree of dysplasia and pleomorphism and a second spindle cell high-grade neoplastic growth with bizarre giant cells and abnormal mitotic figures. Consistent with carcinosarcoma, immunohistochemistry showed strong positive staining for vimentin in the spindle cell component and strong positive staining for cytokeratin markers in the epithelial cell component. The patient underwent right total maxillectomy with postoperative chemoradiation therapy and survived for 1 year.

Carcinosarcoma of the maxillary sinus is a rare disease with non-specific symptoms; it usually presents in the advance stage and is associated with poor patient prognosis. This case indicates that surgical intervention with postoperative chemoradiotherapy improves patient prognosis and should be considered as the standard therapeutic modality.

Carcinoma • Carcinosarcoma • Maxillary Sinus Neoplasms • Paranasal Sinus Neoplasms

http://www.amjcaserep.com/abstract/index/idArt/891007 


\section{Background}

Carcinosarcomas (also known as pseudosarcoma, pseudosarcomatous squamous cell carcinoma, pleomorphic carcinoma, and spindle cell carcinoma) are biphasic tumors with highly aggressive behavior. They are characterized by dual malignant histologic differentiation with an epithelial component consisting of focal squamous cell carcinoma and a mesenchymal component with sarcomatoid stroma [1].

Carcinosarcoma may arise in squamous epithelium in any part of the body and has been reported to occur in the upper aerodigestive tract, salivary glands, thyroid, thymus, lung, breast, gastrointestinal tract, hepatobiliary system, genitourinary tract, and uterus; however, its occurrence in the sinonasal cavity is extremely rare [2-9]. In this report, we present a case of right carcinosarcoma of the maxillary sinus and briefly discuss the management and follow-up of the case, with a review of the literature on this rare tumor.

\section{Case Report}

Following hospital ethics committee approval, a 52-year-old man presented to the ear, nose, and throat clinic of King Abdulaziz University Hospital (a tertiary care hospital in Jeddah, Saudi Arabia) complaining of right nasal obstruction that progressed over 2 months, which was associated with numbness and pain in the right cheek. The patient had experienced intermittent mild epistaxis for 2 weeks prior to presentation. During this period, he was using decongestant nasal drops to relieve the obstruction. He did not report symptoms such as allergic rhinitis symptoms, postnasal drip, decreased hearing, visual problems, or headache. The patient had no significant medical history or any associated comorbid conditions. He lived and was raised in Sanjure City in Indonesia (known to have wood, cement, and steel factories), where he had been working mostly as a tobacco farmer, and he had a history of smoking tobacco since the age of 20 years.

Endoscopic examination revealed a fleshy mass filling the rightside nasal cavity, but there was no cheek fullness. An ear examination revealed a dull tympanic membrane in the right ear. No lymph node abnormalities were detected during a head and neck examination, and the findings of cranial nerve examination were normal. Systemic examination findings were also unremarkable. Computed tomography (CT) of the paranasal sinus (PNS) showed that the right frontal, sphenoid, ethmoid, and maxillary sinuses were opacified, with soft tissue density and expansion of the mass, with erosion of the right lateral maxillary wall (Figures 1 and 2).

The patient underwent functional endoscopic sinus surgery (FESS), which showed a very firm mass involving the right

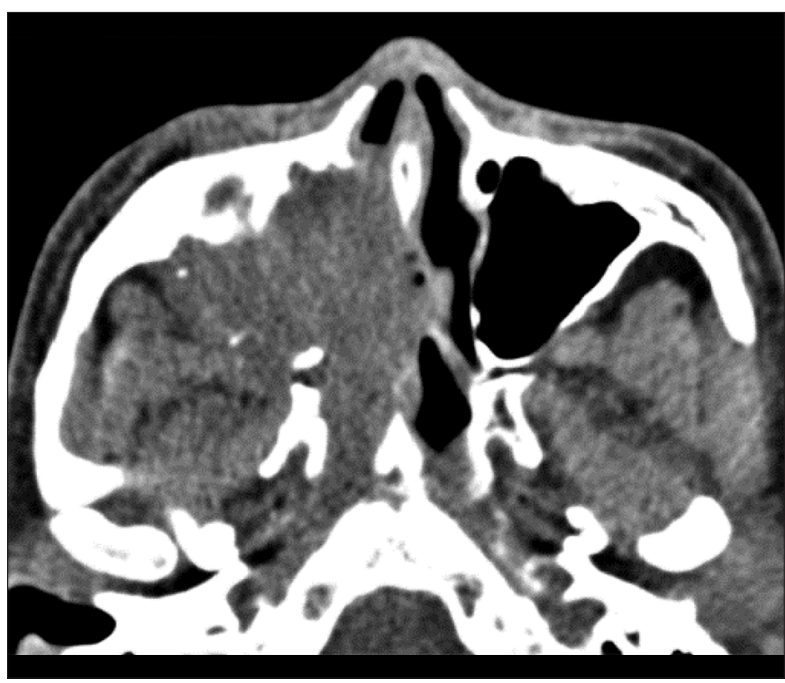

Figure 1. Pre-operative computed tomography scan of the paranasal sinus showing a mass involving the right maxillary sinus (transverse cut).

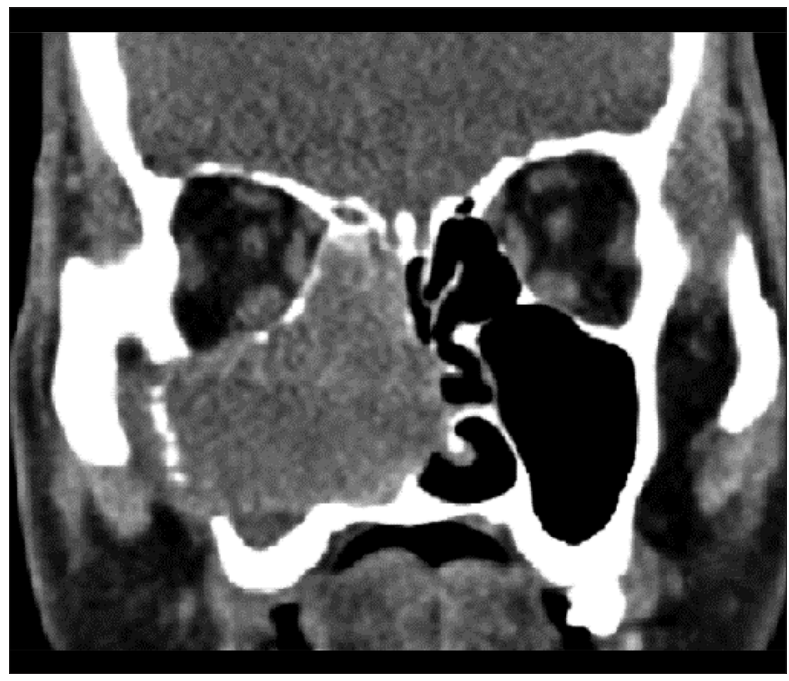

Figure 2. Pre-operative computed tomography scan of the paranasal sinus showing a mass involving the right maxillary sinus (coronal cut).

nasal cavity that was eroding the posterior wall of the maxillary sinus. Intraoperative hemorrhaging occurred from the internal maxillary artery and was controlled by bipolar cauterization and packing. Postoperative MRI scans revealed an enhancing mass along the anterior wall of the right maxillary sinus, with an invasion of the lateral wall and extension up to the posterior edge of the infratemporal fossa. Minor enhancement was apparent along the lateral pterygoid muscles, but there was no evidence of pterygoid destruction, and the mass involved the inferior wall of maxillary sinus, with a small extension to the palate. There was no evidence of intracranial or orbital extension. 

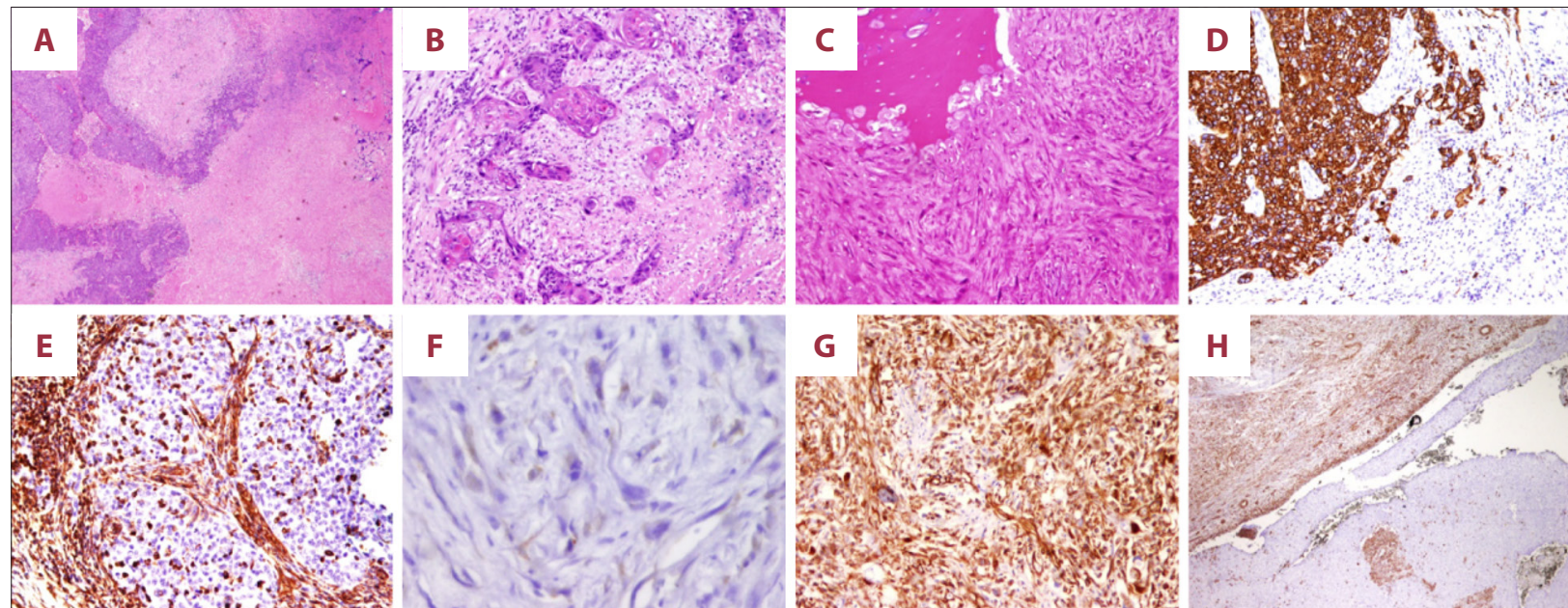

Figure 3. Histopathological staining of tumor biopsy specimens. (A) Squamous cell carcinoma with necrosis. (B) Squamous cells with keratinization. (C) Spindle component invading bone. (D) Positive cytokeratin staining in squamous cells. (E) Negative vimentin staining in squamous cells. (F) Negative cytokeratin staining in spindle cells. (G) Positive vimentin staining in spindle cells. (H) Negative vimentin staining in squamous cells, and positive vimentin staining in spindle cells.

An excisional biopsy specimen of the mass was sent for histopathological analysis. Histopathology revealed multiple fragments of nasal mucosa lined by stratified hyperplastic squamous epithelium, with an increased degree of dysplasia and pleomorphism and a second spindle cell high-grade neoplastic growth with bizarre giant cells and abnormal mitotic figures. Consistent with carcinosarcoma, immunohistochemistry showed strong positive staining for vimentin in the spindle cell component and strong positive staining for cytokeratin markers in the epithelial cell component (Figure 3).

A metastatic work-up revealed negative lab results, and no abnormalities in CT scans of the neck, chest, abdomen, or brain. The clinical TNM staging of the patient was T4aNOMO (Stage 4a).

The patient underwent right total maxillectomy through a Weber-Ferguson incision and lip splitting. The mass was removed en bloc and was found to also involve the posterior orbital wall in addition to the previously mentioned sites. A surgical obturator was placed with the assistance of the maxillofacial surgical team. Postoperative histopathology of the mass confirmed the diagnosis of carcinosarcoma of the maxillary sinus.

The patient received postoperative chemoradiation therapy consisting of 2 cycles of cisplatin $\left(30 \mathrm{mg} / \mathrm{m}^{2}\right)$ intravenously infused with $500 \mathrm{~mL}$ normal saline over $2 \mathrm{~h}$ and intensitymodulated radiation therapy (IMRT) over the right maxilla for a total of 70 Gy in 35 fractions. To date, there is no evidence of tumor recurrence in the right maxillary sinus region on MRI scans, 1 year later (Figure 4). However, the patient exhibited soft tissue thickening, nodularity, and enhancement in the remainder of the right side of the soft palate, and recurrence

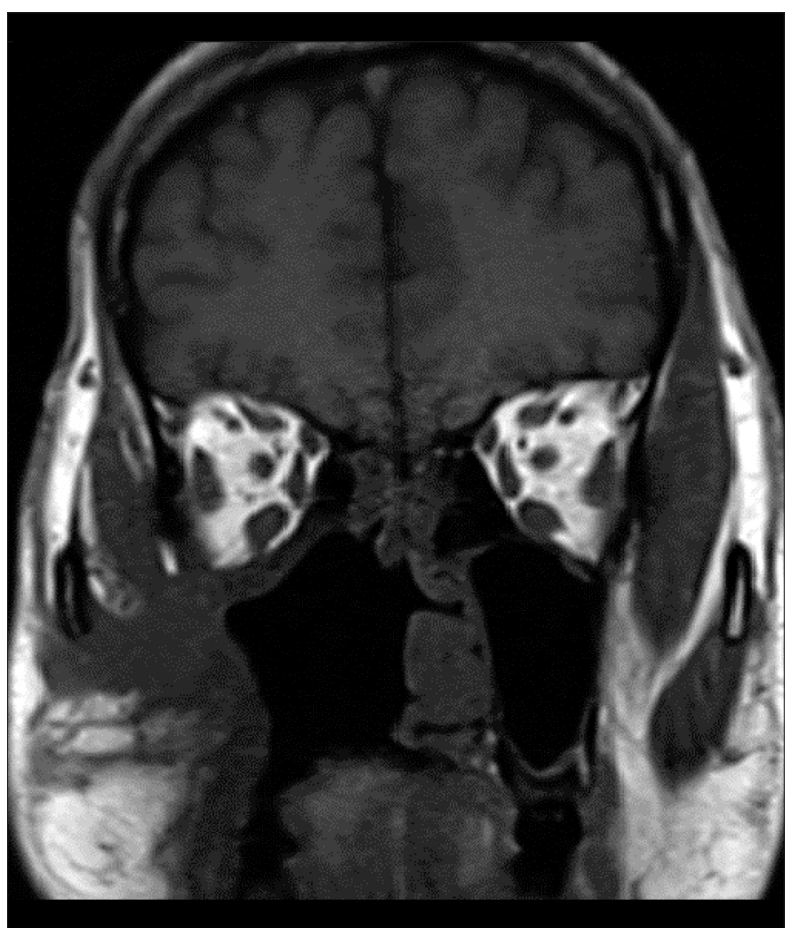

Figure 4. Magnetic resonance imaging 1 year after total maxillectomy with preservation of the eye.

was suspected in the left side of the soft palate, but the patient has refused any further management.

\section{Discussion}

Carcinosarcomas are biphasic tumors with dual components: an epithelial, squamous cell carcinoma component and a 
Table 1. A review of similar cases in the published literature.

\begin{tabular}{|c|c|c|c|c|c|}
\hline No & Age/sex & Stage & Treatment & Outcome & Author, year \\
\hline 1 & $62 / F$ & & Radiotherapy & $\begin{array}{l}\text { No marked improvement } \\
\text { of the tumor, dead with } \\
\text { disease }\end{array}$ & Meyer, 1957 \\
\hline 2 & $62 / F$ & & Radiotherapy & Death in 40 months & Lichtiger, 1970 \\
\hline 3 & $71 / M$ & T4NOMO & $\begin{array}{l}\text { Preoperative radiotherapy }+ \text { total } \\
\text { maxillectomy }+ \text { removal of eye }\end{array}$ & $\begin{array}{l}\text { Death due to intracerebral } \\
\text { abscess at postoperative } \\
\text { period }\end{array}$ & Feinmesser, 1982 \\
\hline 4 & $65 / F$ & & Total maxillectomy + radiotherapy & $\begin{array}{l}\text { Local recurrence, death } 8 \\
\text { months later }\end{array}$ & Ampil, 1985 \\
\hline 5 & $57 / F$ & & $\begin{array}{l}\text { Tumor excision, ethmoidectomy } \\
\text { and turbinectomy }\end{array}$ & $\begin{array}{l}\text { Local recurrence } 5 \text { months } \\
\text { after surgery }\end{array}$ & Hafiz, 1987 \\
\hline 6 & $60 / M$ & T3NOMO & $\begin{array}{l}\text { Total maxillectomy + radiation } \\
\text { therapy + chemotherapy }\end{array}$ & $\begin{array}{l}\text { Local recurrence, death } 2 \\
\text { months later }\end{array}$ & Sonobe, 1989 \\
\hline 7 & $53 / M$ & T4NOMO & $\begin{array}{l}\text { Total maxillectomy + craniofacial } \\
\text { resection + radiation therapy } \\
\text { + chemotherapy }\end{array}$ & $\begin{array}{l}\text { Disease free after } 9 \\
\text { months }\end{array}$ & Shindo, 1990 \\
\hline 8 & $80 / F$ & T3NOMO & $\begin{array}{l}\text { Total maxillectomy + radiation } \\
\text { therapy }+2 \text { nd operation }\end{array}$ & $\begin{array}{l}\text { Local recurrence, death } \\
2 \text { months after second } \\
\text { operation }\end{array}$ & Sanabre, 1998 \\
\hline 9 & $47 / M$ & & $\begin{array}{l}\text { Partial maxillectomy + radiation } \\
\text { therapy }\end{array}$ & $\begin{array}{l}\text { Local recurrence, death } \\
\text { after } 1 \text { year }\end{array}$ & Furuta, 2001 \\
\hline 10 & $54 / M$ & T3N3MO & Radiation therapy + chemotherapy & Death after 4 months & Howard, 2007 \\
\hline 11 & $60 / M$ & T3NOMO & $\begin{array}{l}\text { Total maxillectomy + radiation } \\
\text { therapy + chemotherapy }\end{array}$ & Local recurrence & Jeong-Ki Moon, 2009 \\
\hline 12 & $52 / M$ & T4aNOMO & $\begin{array}{l}\text { Total maxillectomy + radiation } \\
\text { therapy + chemotherapy }\end{array}$ & $\begin{array}{l}\text { Local recurrence (soft } \\
\text { palate) }\end{array}$ & Current case, 2012 \\
\hline
\end{tabular}

sarcomatoid component. This tumor can arise in the squamous epithelium in any part of the body. In the head and neck region, it commonly occurs in the pharynx or larynx [10] and is extremely rare in the sinonasal cavity $[2,4]$. Management strategies, tumor histogenesis, and the clinical course for such cases are controversial because of the limited number of cases reported in the literature (Table 1).

Two hypotheses for the origin of carcinosarcoma have been proposed. The convergence hypothesis suggests that a heterologous tumor originates from 2 stem-cell lines, whereas the divergence hypothesis suggests that the tumor originates from a single stem cell that differentiates into epithelial and sarcomatous components [2]. A recent study reported epithelial differentiation in some spindle cells in the sarcomatous component, suggesting that this component is derived from the mesenchymal transformation of the carcinoma cells, supporting the divergence hypothesis [11].

Including the current case, 18 cases diagnosed as carcinosarcoma of the maxillary sinus have been reported since 1957
(Table 1) [2-9,11-13]; 6 of them provided insufficient clinical information [14]. Carcinosarcoma of the maxillary sinus is mostly reported in older patients aged $47-80$ years. Seven cases involved men and 5 cases involved women. There are no specific symptoms associated with carcinosarcoma of the maxillary sinus, but a history of unilateral nasal obstruction and epistaxis were common symptoms in all reported cases. The non-specific symptoms of carcinosarcoma of the maxillary sinus complicate an early diagnosis; patients often present late, creating a therapeutic challenge and increasing the likelihood of a poor prognosis.

Eight of the 11 previous cases underwent total maxillectomy and almost all had radiotherapy with or without surgery. Patients that were treated with surgery and adjuvant chemoradiation therapy tended to have a better prognosis. In the current case, the carcinosarcoma of the maxillary sinus was managed with a total maxillectomy and postoperative chemoradiation therapy.

Since the number of reported cases of carcinosarcoma of the maxillary sinus is small, it is difficult to report survival, 
recurrence, and mortality rates. An overall mortality rate of $42 \%$ at 30 months was reported for carcinosarcoma at different sites [15]. Of the 12 cases discussed here, tumor recurrence occurred in 8 .

\section{Conclusions}

Carcinosarcoma of the maxillary sinus is a rare disease with non-specific symptoms; it usually presents in the advance stage and is associated with poor patient prognosis. The small number of reported cases creates an obstacle to the increased understanding of the behavior, prognosis, and therapeutic

\section{References:}

1. Middlehurst RJ, Blackburn CW, Sloan P: Spindle-cell carcinoma: a case report. Br J Oral Maxillofac Surg, 1990; 28: 114-16

2. Furuta $\mathrm{Y}$, Nojima T, Terakura $\mathrm{N}$ et al: $\mathrm{A}$ rare case of carcinosarcoma of the maxillary sinus with osteosarcomatous differentiation. Auris Nasus Larynx, 2001; 28(Suppl.): S127-29

3. Feinmesser R, Wiesel J, Deutsch E et al: Carcinosarcoma of the nose and paranasal sinuses-a case report. Rhinology, 1982; 20: 167-70

4. Meyer I, Shklar G: Carcinosarcoma of the maxillary sinus: report of a case. Oral Surg Oral Med Oral Pathol, 1957; 10: 1065-74

5. Sanabre AA, Gonzalez-Lagunas J, Redecilla PH, Martin GR: Carcinosarcoma of the maxillary sinus: a case report. J Oral Maxillofac Surg, 1998; 56: 1456-60

6. Howard SN, Bond WR, Hong IS, Foss RD: Right maxillary sinus sarcomatoid carcinoma (sarcomatoid/spindle cell carcinoma). Otolaryngol Head Neck Surg, 2007; 137: 355-57

7. Hafiz MA, Mira J, Toker C: Postirradiation carcinosarcoma of the nasal cavity. Otolaryngol Head Neck Surg, 1987; 97: 319-21

8. Moon JK, Kim AY, Chang DS, Park KY: Carcinosarcoma of the maxillary sinus. Clin Exp Otorhinolaryngol, 2013; 6: 114-16 management of this tumor type. This case indicates that surgical intervention with postoperative chemoradiation therapy improves patient prognosis and should be considered as the standard therapeutic modality. Further prospective randomized studies are necessary to confirm such intervention.

\section{Acknowledgments}

We would like to express our special appreciation and thanks to Dr. Saad M. Almuhayawi, MD, FRCSC, and Dr. Talal Alkhatib $M D$, FRCSC, for their effort and expertise in the management of this patient, especially in performing the total maxillectomy surgery.

9. Shindo ML, Stanley RB Jr, Kiyabu MT: Carcinosarcoma of the nasal cavity and paranasal sinuses. Head Neck, 1990; 12: 516-19

10. Goellner JR, Devine KD, Weiland LH: Pseudosarcoma of the larynx. Am J Clin Pathol, 1973; 59: 312-26

11. Lichtiger B, Mackay B, Tessmer CF: Spindle-cell variant of squamous carcinoma. A light and electron microscopic study of 13 cases. Cancer, 1970; 26: $1311-20$

12. Ampil FL: The controversial role of radiotherapy in spindle cell carcinoma (pseudosarcoma) of the Head and Neck. Radiat Med, 1985; 3(4): 225-29

13. Sonobe H, Hayashi K, Takahashi K, Ohtosuki Y, Kishimoto S, Saito H, Honio I. True carcinosarcoma of the maxillary sinus. Pathol Res Pract, 1989; 185(4): 488-92

14. Viswanathan S, Rahman K, Pallavi S: Sarcomatoid (Spindle Cell) Carcinoma of the Head and Neck Mucosal Region: A Clinicopathologic Review of 103 Cases from a Tertiary Referral Cancer Centre. Head Neck Pathol, 2010; 4(4): 265-75

15. Batsakis JG: "Pseudosarcoma" of the mucous membranes in the head and neck. J Laryngol Otol, 1981; 95: 311-16 